Gribenski, N., et al., 2021, Out-of-phase Late Pleistocene glacial maxima in the Western Alps reflect past changes in North Atlantic atmospheric circulation: Geology, v. 49, https://doi.org/10.1130/G48688.1

\title{
Out-of-phase Late Pleistocene glacier maxima in the Western Alps reflect past changes in North Atlantic atmospheric circulation
}

Natacha Gribenski ${ }^{1}$, Pierre G. Valla ${ }^{2,1}$, Frank Preusser ${ }^{3}$, Thibault Roattino ${ }^{2}$, Christian Crouzet $^{2}$, Jean François Buoncristiani ${ }^{4}$

${ }^{1}$ Institut of Geological Sciences, University of Bern, Bern, Switzerland (natacha.gribenski@geo.unibe.ch)

${ }^{2}$ ISTerre, Université Grenoble Alpes, Université Savoie Mont Blanc, CNRS, IRD, IFSTAR, Grenoble, France

${ }^{3}$ Institute of Earth and Environmental Sciences, University of Freiburg, Freiburg, Germany

${ }^{4}$ UMR 6282 Biogéosciences, CNRS/Univ Bourgogne Franche-Comté, Dijon, France

\section{GSA Data Repository}

\section{Content:}

\section{Geomorphic context and sedimentology}

- General geomorphic classification and detailed information per sampling sites

- Table S1: sample location details

- $\quad$ Figures S1 to S7: Detailed geomorphic and sedimentological context per sampling site

- $\quad$ Figure S8: Geomorphic mapping of overridden moraine ridges

\section{Optically stimulated luminescence dating}

- Sample preparation, measurement and data analysis

- $\quad$ Figure S9: dose recovery tests

- $\quad$ Figure S10, S11: fading measurements (multi and single grain scale)

- Figure S12: comparison of FMM burial equivalent doses for varying $\sigma_{b}$

- Figure S13, S14: single grain equivalent dose distributions (quartz and feldspar)

- Table S2: SAR measurement protocols

- $\quad$ Tables S3, S4: summary of luminescence dating (feldspar and quartz)

- $\quad$ Table S5: element concentrations for dose rate determination 


\section{Geomorphic context and sedimentology}

\section{Geomorphic terrace and moraine classification}

Previous studies have been conducted in the Lyon area and distinguished several substages associated with the IMC, based on glaciofluvial and moraine ridges stratigraphic correlations.

Mandier (1988) identified four Late Pleistocene glacial stages, from A to D, within the IMC, based on geomorphology and morphostratigraphy relationships between moraine ridges and glaciofluvial terraces. Stage A corresponds to the maximum ice extent (outermost and highest moraine ridge connected with the highest terrace level), and stage D corresponds to the smallest ice extent (inner and lowermost moraine ridge connected with the lowest terrace level).

Roattino et al. (2021) identified three main glaciofluvial terraces, from FgW1(highest) to FgW3 (lowest), connected with moraine ridges from the IMC, based on remote sensing cross checked with borehole data and on field sedimentological and geomorphological investigations.

In the present study, we mainly followed the classification of Roattino et al. (2021), such as terrace levels FgW1, FgW2 and FgW3 correspond to the high, middle and low terrace levels (T1/T2, T3 and T4), connected with the external, middle and internal moraine ridges (M2, M3 and M4). We however do recognise the presence of a fourth moraine ridge (M1) clearly visible in the NW part of the study area, uncovered by Roattino et al. (2021). As a consequence, we propose two possible (and geomophologically very similar) high terrace levels T1/T2 for the rest of the study area, connected to the most external moraine ridge (M2, possibly including some remnants of M1 deposits).

In total, eight samples were collected in six sampling sites distributed across the study area, and from glaciofluvial geomorphic units representative of the different substages identified in the area (Table S1).

\section{OSL sampling sites: detailed geomorphic and sedimentological context}

For each sampling site, detailed information about the geomorphological and sedimentological context are provided in the Figures S2 to S7, as follow:

1) Geomorphological map (zoom locations as red boxes in the general geomorphological map below);

2) Representative longitudinal and transect profiles. These profiles do not directly intersect with the sampling site as they were first selected to best illustrate the general topographic/geomorphic context of the sampling area. However, the approximate location of the logged sedimentary section is indicated in the most relevant longitudinal/cross profile (note: the logged section symbol is not scaled and its absolute top elevation does not always fit within the elevation range of the topographic profile);

3) Detailed sedimentological log at the sampling site. Main sedimentary facies and sample location within the sedimentary section are indicated. The absolute elevation of the top of the $\log$ corresponds to the terrace surface at the sampling site. 
Table S1: Sample locations and geomorphological information

\begin{tabular}{|c|c|c|c|c|c|c|c|}
\hline Sample ID & $\begin{array}{l}\text { Sampling site } \\
\text { locality }\end{array}$ & $\begin{array}{c}\text { Latitude/ } \\
\text { Longitude } \\
\left({ }^{\circ} \mathbf{N} /{ }^{\circ} \mathbf{E}\right)\end{array}$ & $\begin{array}{c}\text { Elevation } \\
\text { (m a.s.l.) }\end{array}$ & $\begin{array}{c}\text { Depth } \\
\text { (m below } \\
\text { surface) }\end{array}$ & $\begin{array}{l}\text { Geomorphic unit } \\
\text { (Mandier, 1988) }\end{array}$ & $\begin{array}{c}\text { Geomorphic unit } \\
\text { Roattino et al. (2021)* }\end{array}$ & $\begin{array}{c}\text { Geomorphic unit } \\
\text { This study*** }\end{array}$ \\
\hline EYP1 & $\begin{array}{l}\text { Eyzin Pinet } \\
\text { (EYP) }\end{array}$ & $45.496 / 5.009$ & 262 & 5 & Terrace level B & FgW2 & Т3 \\
\hline OYT1 & Oytier (OYT) & $45.575 / 5.030$ & 265 & 3.2 & Terrace level B/C & FgW2 & T3 \\
\hline SPC5 & $\begin{array}{c}\text { St Pierre de } \\
\text { Chandieux (SPC) }\end{array}$ & $45.666 / 5.015$ & 250 & 5 & Terrace level B & FgW1 & $\mathrm{T} 1 / \mathrm{T} 2$ \\
\hline ART1 & Artas (ART) & $45.537 / 5.182$ & 430 & 3 & Terrace level D & FgW3 & $\mathrm{T} 4$ \\
\hline ART2 & Artas (ART) & $45.536 / 5.182$ & 420 & 12 & Terrace level C & FgW2/3 & $\mathrm{T} 3$ or $\mathrm{T} 4$ \\
\hline PEN1 & Penol (PEN) & $45.363 / 5.186$ & 313 & 12 & Terrace level A & FgW1 & $\mathrm{T} 1 / \mathrm{T} 2$ \\
\hline PIZ1 & Pizay (PIZ) & $45.876 / 5.088$ & 250 & 13 & $\begin{array}{l}\text { Underlying till from } \\
\text { the outermost } \\
\text { moraine subset } \\
\text { (stage A) }\end{array}$ & - & underlying M1 \\
\hline PIZ2 & Pizay (PIZ) & $45.876 / 5.088$ & 256 & 2 & $\begin{array}{l}\text { Underlying till from } \\
\text { the outermost } \\
\text { moraine subset } \\
\text { (stage A) }\end{array}$ & - & underlying M1 \\
\hline
\end{tabular}

*This study was conducted across the area covering EYP, OYT, SPC, ART and PEN sampling sites. 
Detailed geomorphic and sedimentological context per sampling site

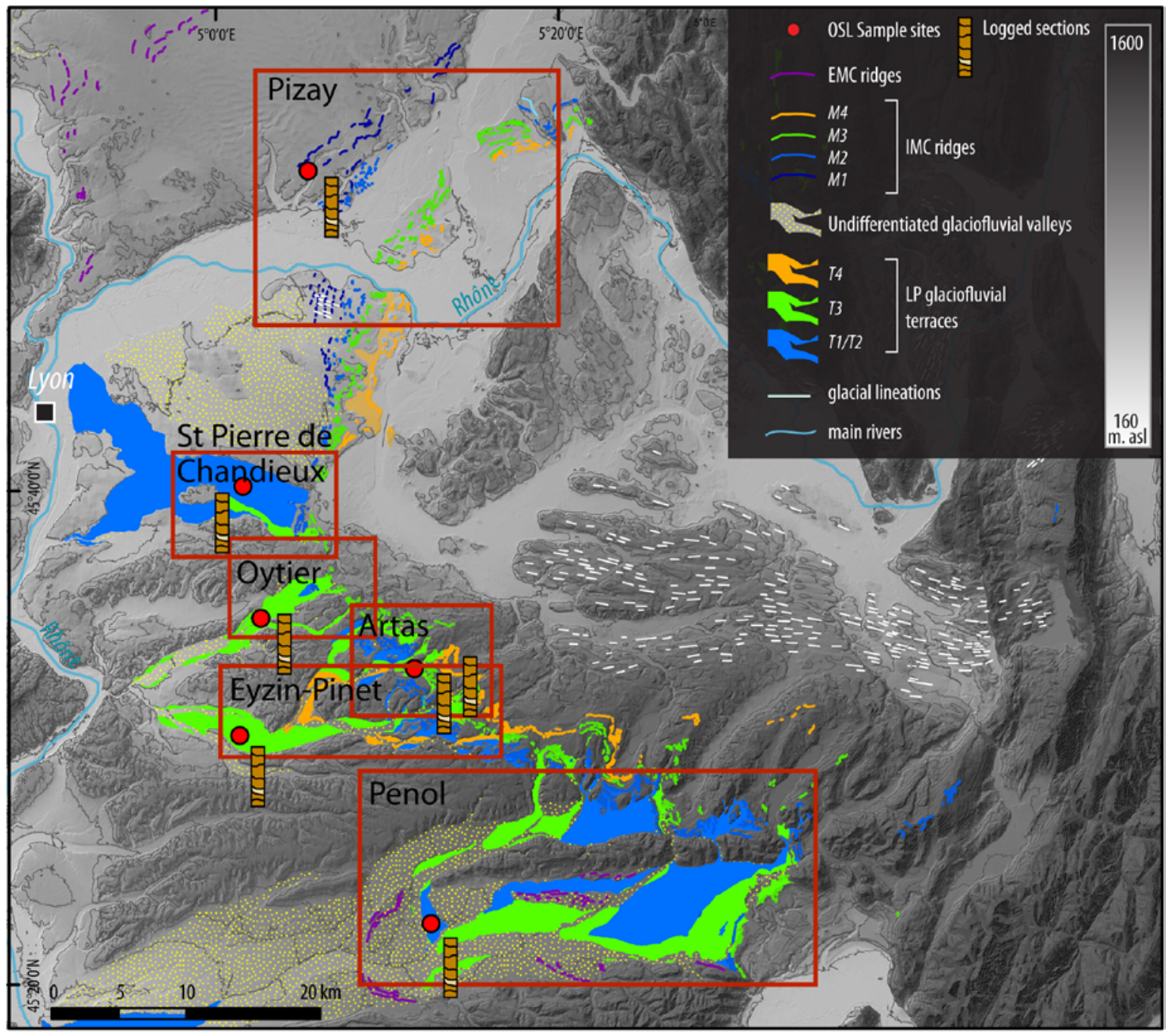

\section{Main sedimentary facies identified in the sedimentary sections logged}

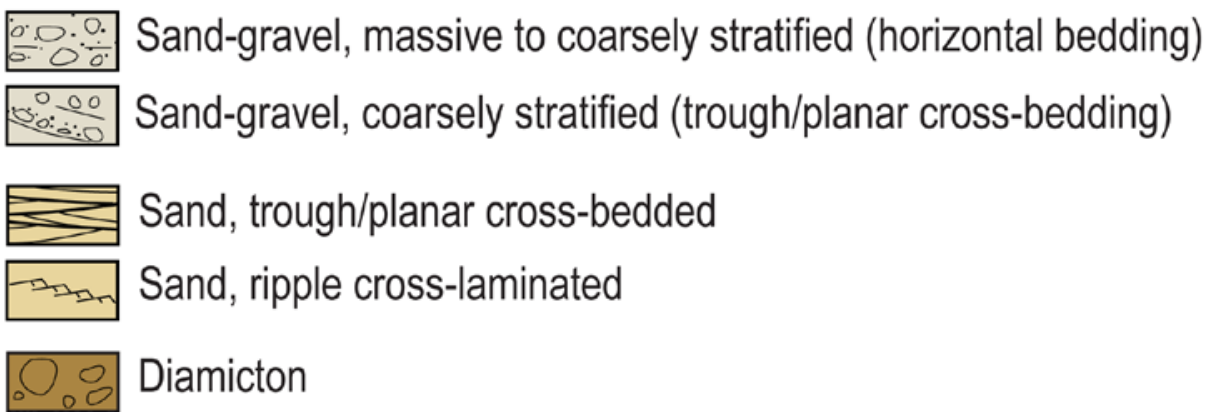

Figure S1: Up: Geomorphological map of the study area. The red boxes correspond to the zoomed areas for each sampling site, and for which a detailed sedimentological log was also recorded in the field. Down: Legend of symbols used to record lithological and structural data (see sedimentological logs after; $S E$ indicates observed erosion surfaces). 


\section{Eyzin-Pinet}

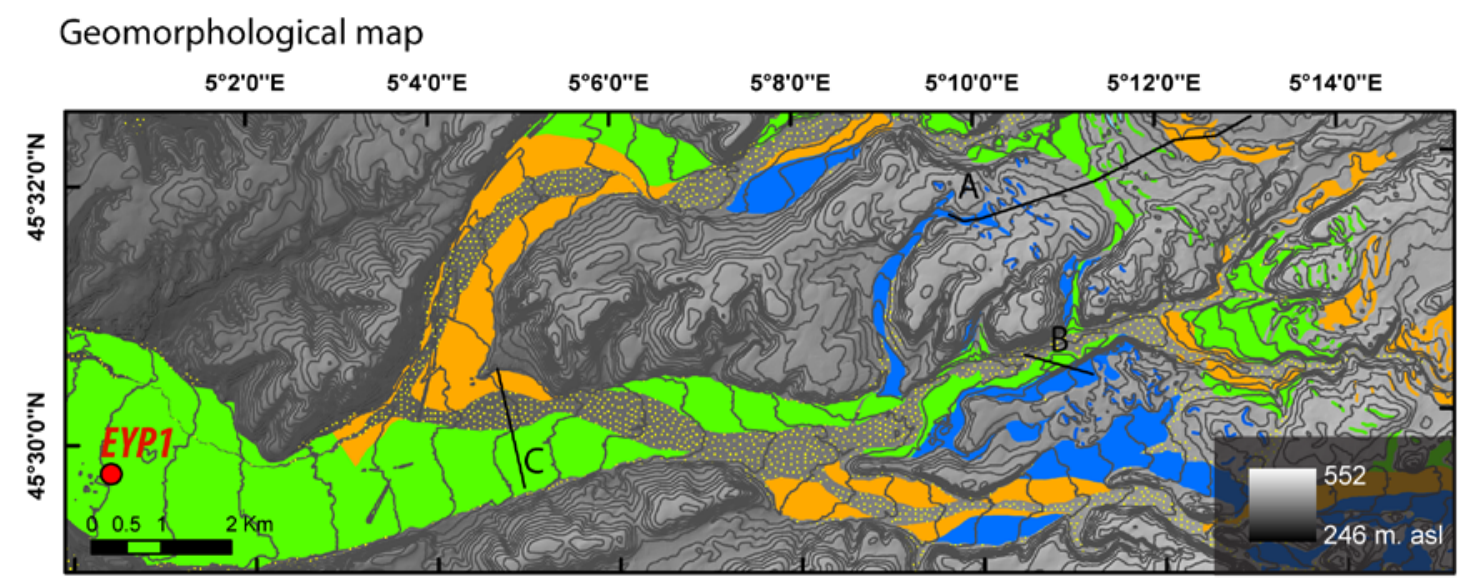

Topographic profiles
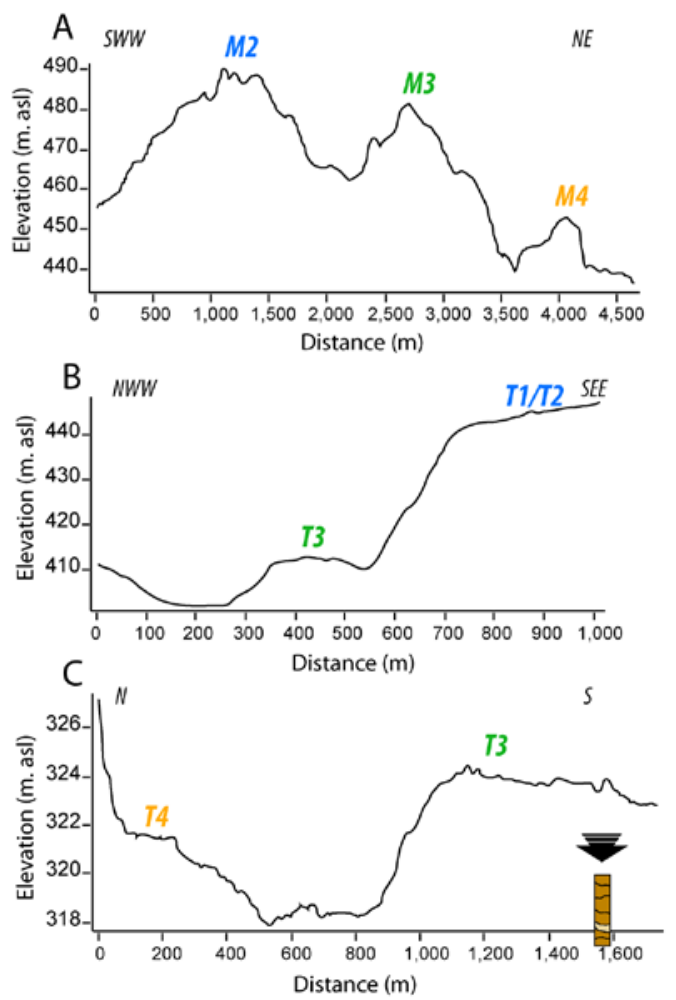

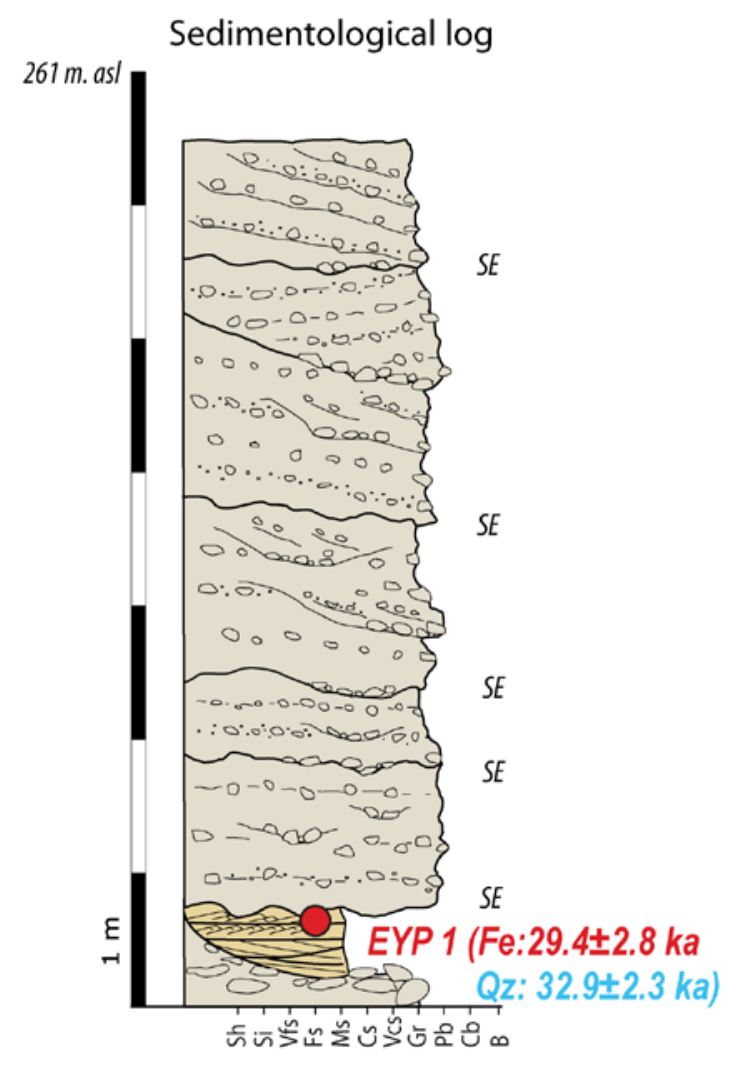

Figure S2: Eyzin-Pinet (EYP) sampling site: detailed geomorphological map (up), longitudinal and cross profiles representative of the glacial/glacio-fluvial geomorphological context (down left), and sedimentological log (down right) with sample measured feldspar $\left(\mathrm{IR}_{50}\right)$ and quartz (green $\left.\mathrm{OSL}\right)$ single-grain ages. 


\section{Oytier}

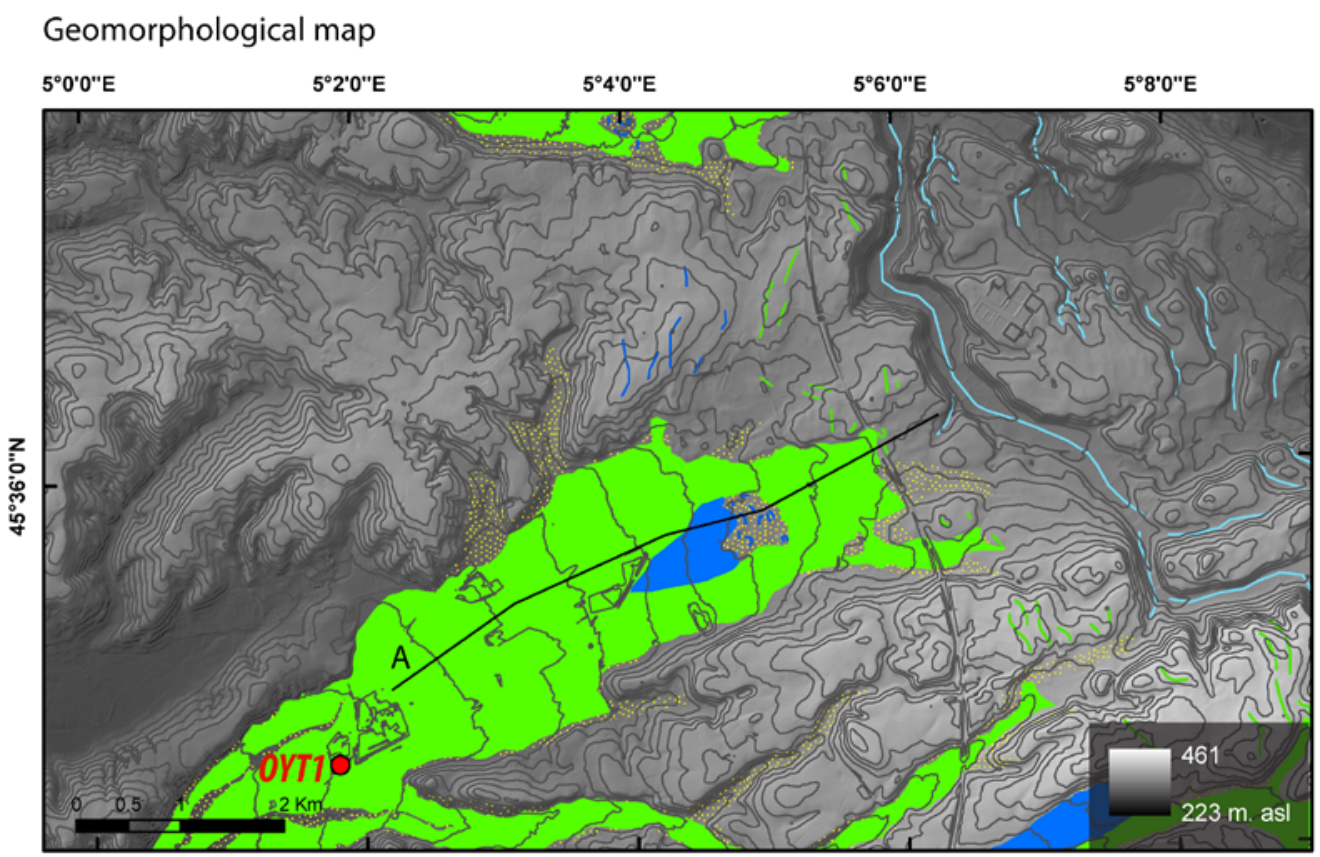

Topographic profiles

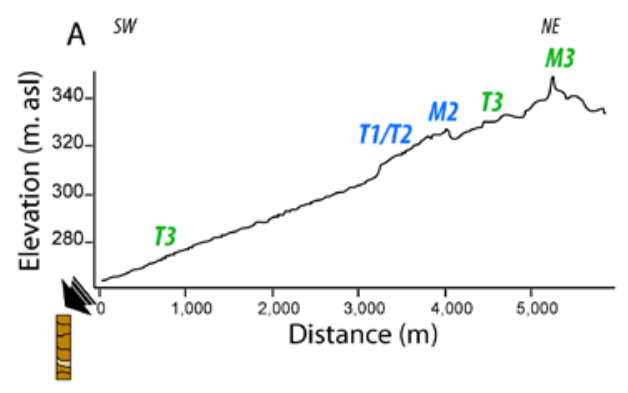

Sedimentological log

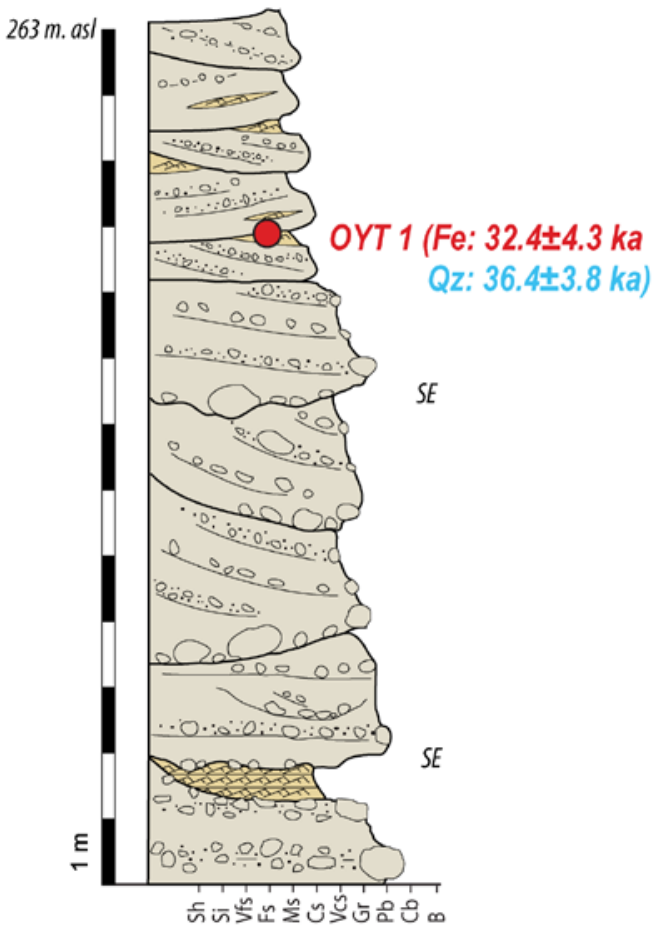

Figure S3: Oytier (OYT) sampling site: detailed geomorphological map (up), longitudinal profile representative of the glacial/glacio-fluvial geomorphological context (down left), and sedimentological log (down right) with sample measured feldspar (IR50) and quartz (green OSL) single-grain ages. 


\section{St Pierre de Chandieux}

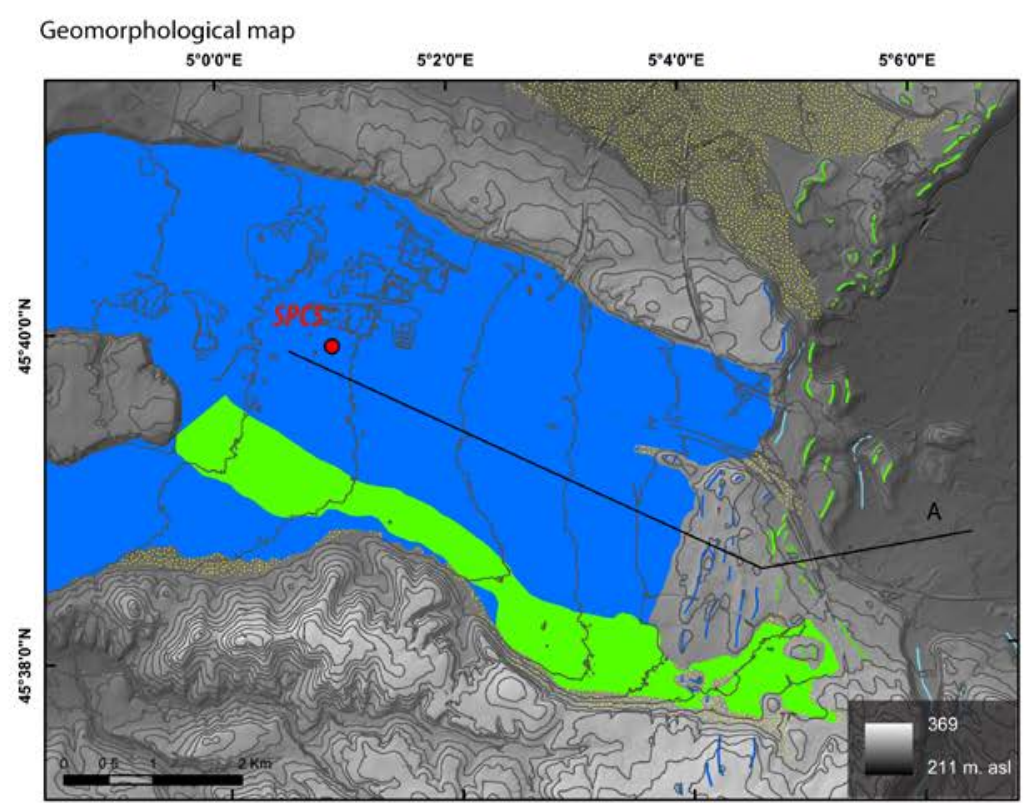

Topographic profile

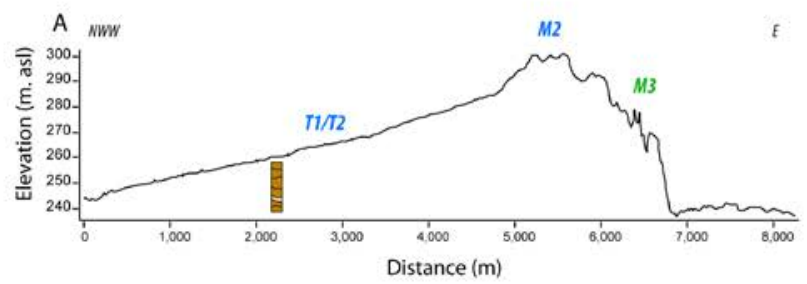

Sedimentological log

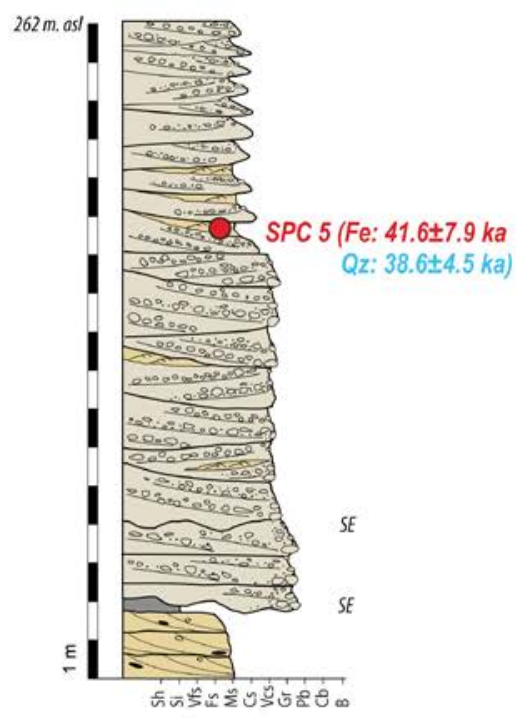

Figure S4: Saint Pierre de Chandieux (SPC) sampling site: detailed geomorphological map (up), longitudinal profile representative of the glacial/glacio-fluvial geomorphological context (down left), and sedimentological log (down right) with sample measured feldspar ( $\mathrm{IR}_{50}$ ) and quartz (green OSL) single-grain ages. 


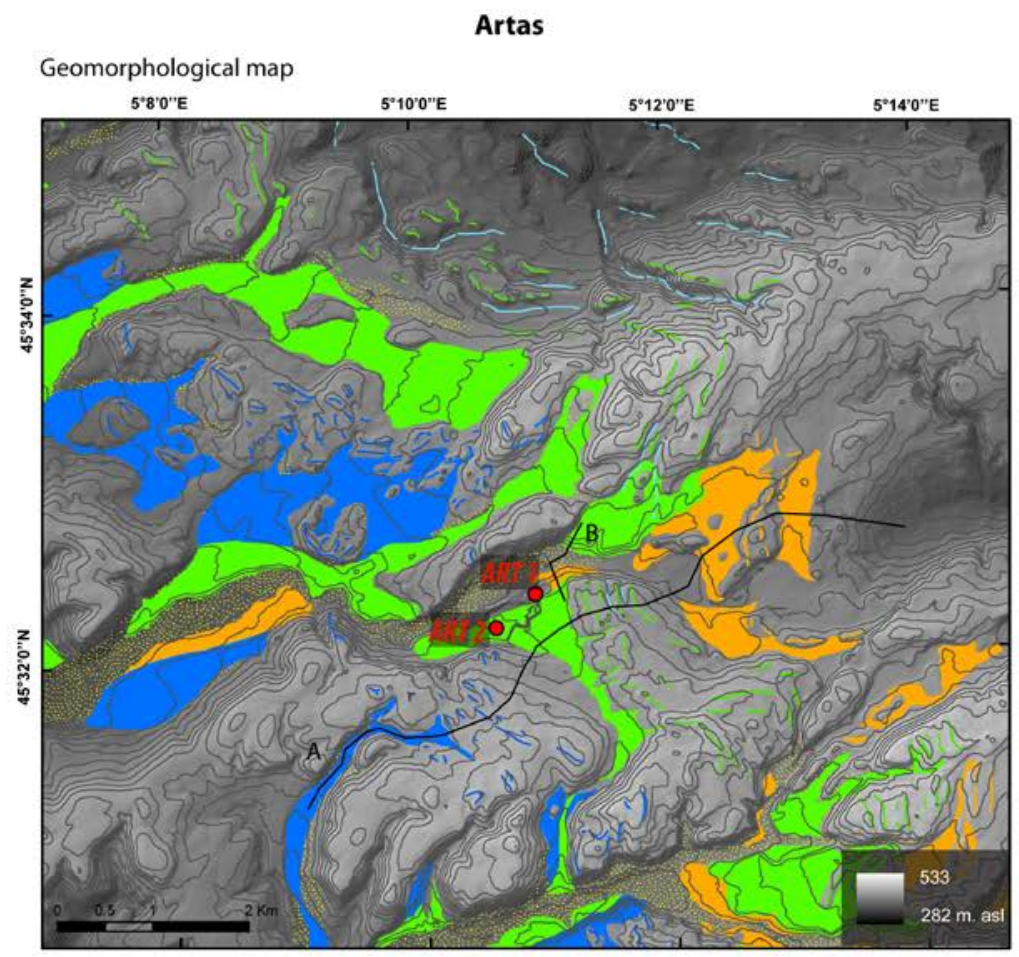

Topographic profiles
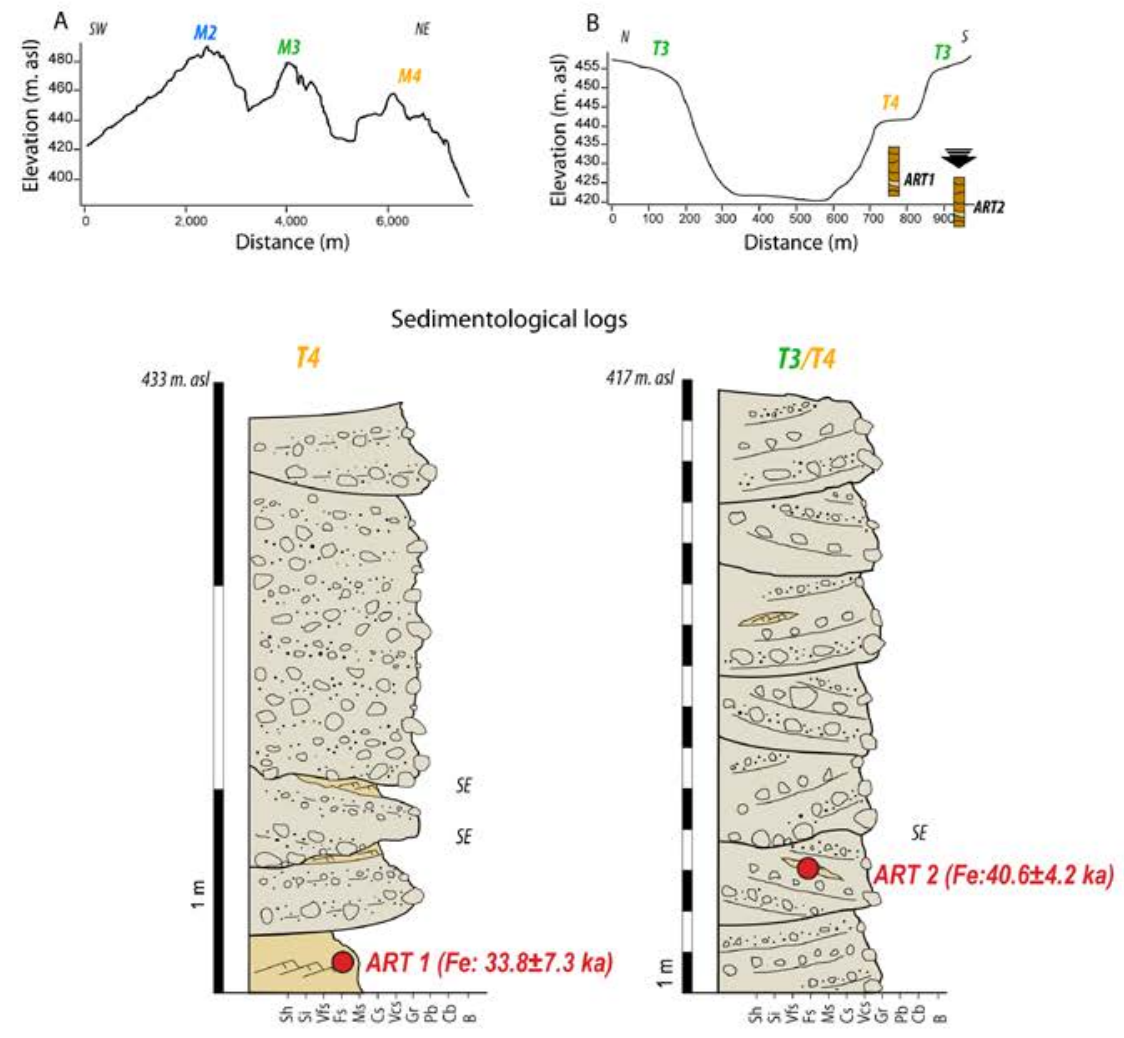

Figure S5: Artas (ART) sampling site: detailed geomorphological map (up), longitudinal and cross profiles representative of the glacial/glacio-fluvial geomorphological context (middle), and sedimentological logs (down) with sample measured feldspar ( $\left.\mathrm{IR}_{50}\right)$ single-grain ages. 


\section{Penol}

\section{Geomorphological map}
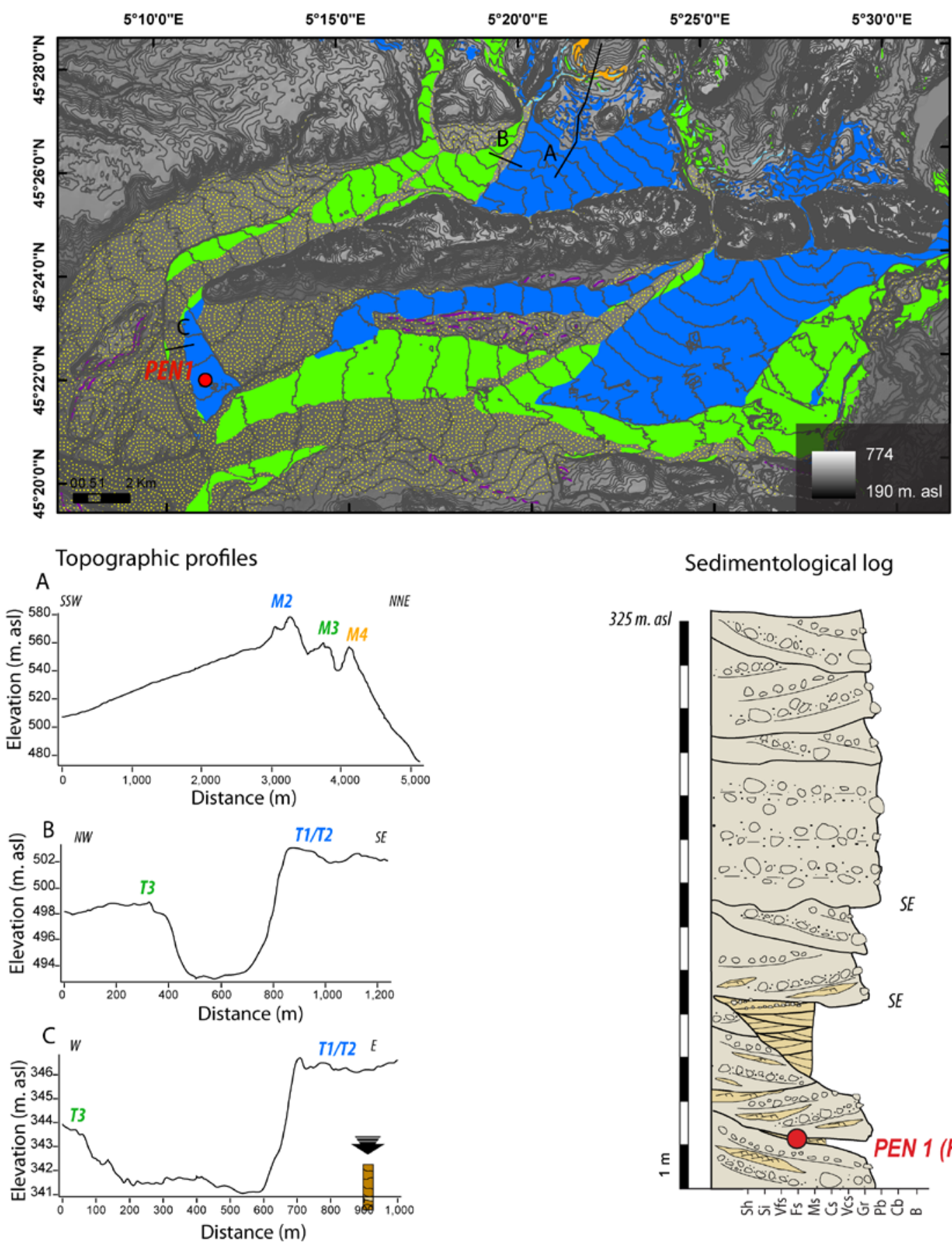

Sedimentological log

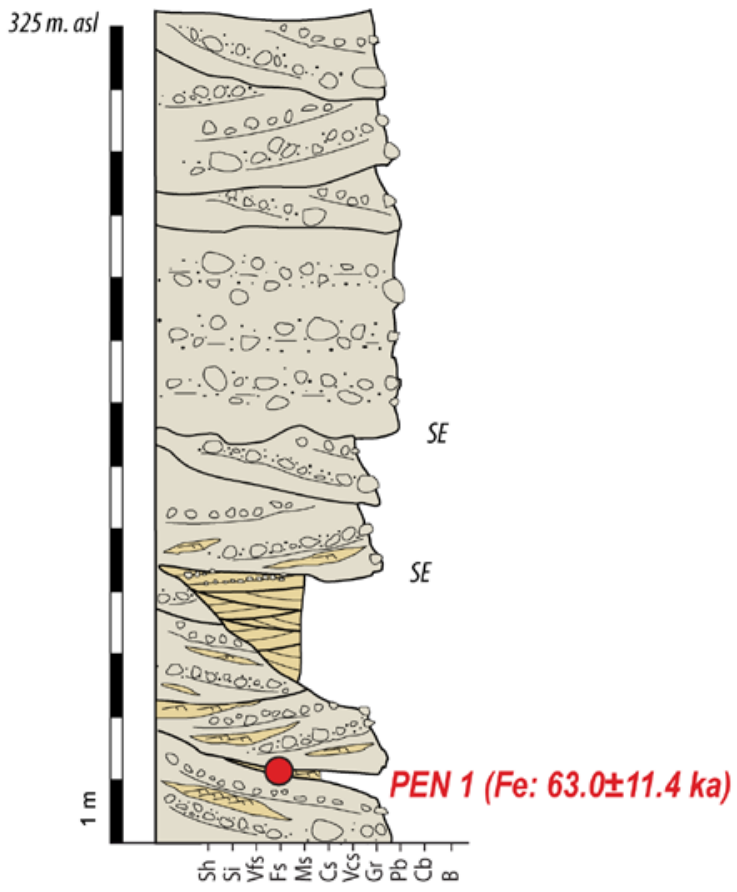

Figure S6: Penol (PEN) sampling site: detailed geomorphological map (up), longitudinal and cross profiles representative of the glacial/glacio-fluvial geomorphological context (down left), and sedimentological log (down right) with sample measured feldspar ( $\mathrm{IR}_{50}$ ) single-grain age. 
Pizay

Geomorphological map Sedimentological log
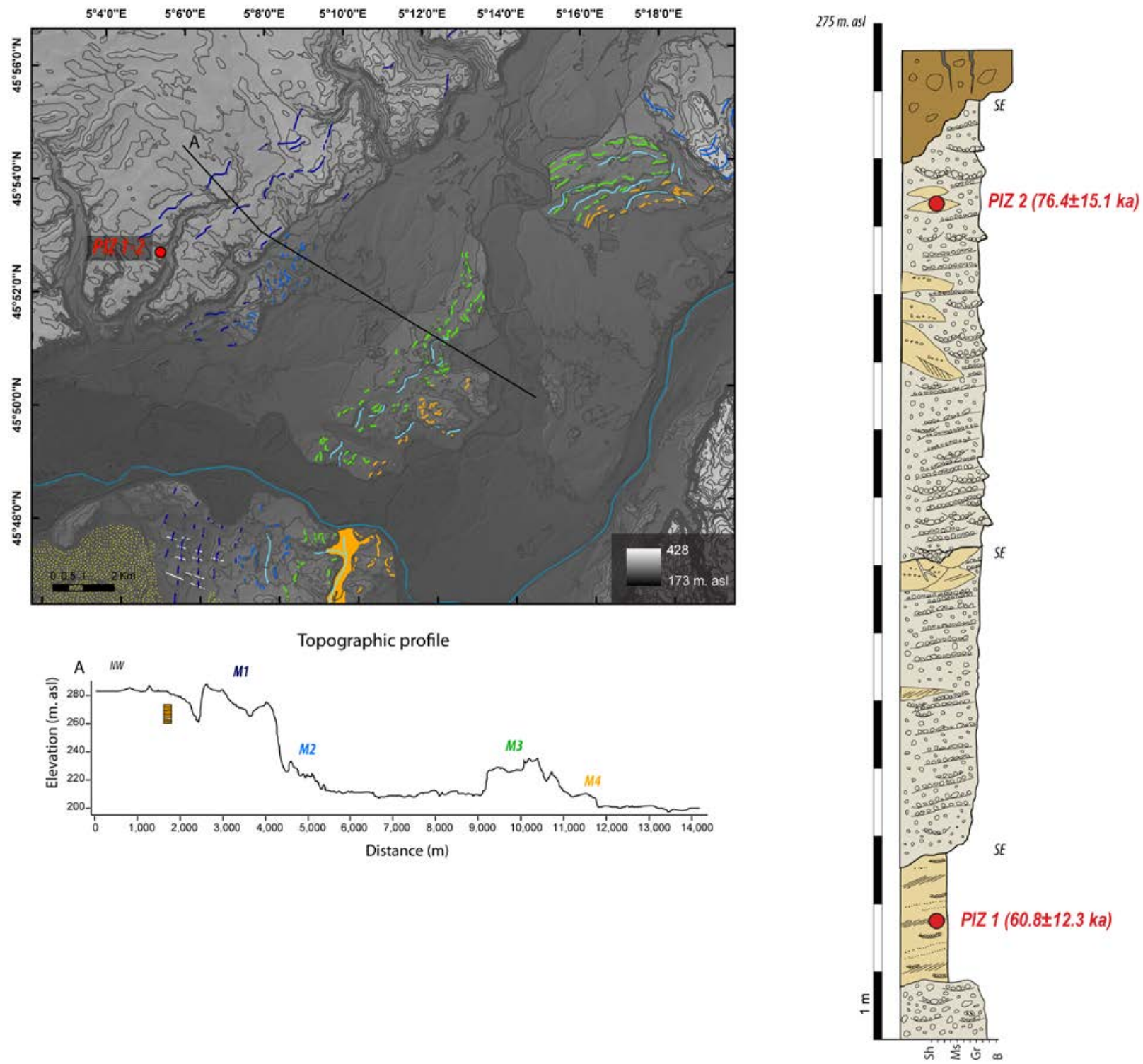

Figure S7: Pizay (PIZ) sampling site: detailed geomorphological map (up), longitudinal profile representative of the glacial/glacio-fluvial geomorphological context (down left), and sedimentological log (down right) with sample measured feldspar ( $\mathrm{IR}_{50}$ ) single-grain ages. 

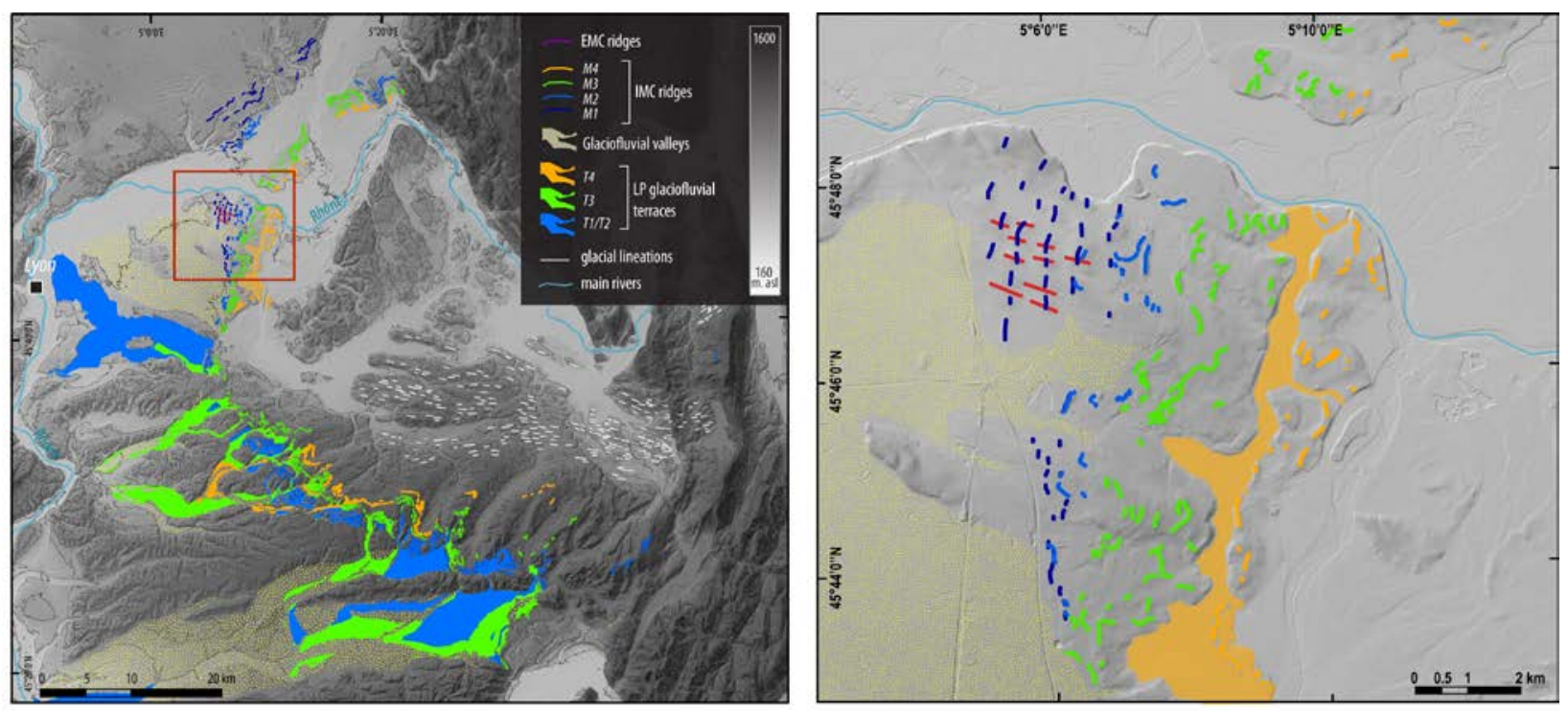

Figure S8: DEM observations (5-m resolution, confirmed by field observations) of overridden moraines (right panel), in the NW of the study area (red box in the left panel), indicated by the presence of subtle lines (straight red lines on the right panel) cross-cutting perpendicularly sinuous positive topographic features (dark blue lines on the right panel) that are aligned with the general IMC ridges pattern (although more discrete). We interpret the latter as older moraine ridges (M1) which have been overridden by subsequent glacier advance. 


\section{Optically stimulated luminescence dating}

\section{Sample preparation, instrumentation and measurement protocols}

Coarse-sand samples were collected in black tubes and prepared in the laboratory under red-light conditions following standard procedures (e.g. Lowick et al., 2015). The 200-250 $\mu \mathrm{m}$ fraction was sieved and treated with $\mathrm{HCl}$ and $\mathrm{H}_{2} \mathrm{O}_{2}$ to remove carbonates and organic components, respectively. Heavy-liquid density separation (sodium heteropolytungstate solution) was applied to isolate feldspar and quartz minerals, and the quartz fraction was etched using HF ( $40 \%$ for $40 \mathrm{~min}$ ). Individual feldspar and quartz grains were placed in separated holes ( 100 holes of $300 \mu \mathrm{m}$ diameter) drilled in a $9.8 \mathrm{~mm}$ diameter aluminium disk for singlegrain luminescence measurements, or mounted on 4-mm aliquots for large-aliquot measurements.

All luminescence measurements were performed at the Institute of Geological Sciences of the University of Bern, Switzerland, on a Risø TL/OSL DA-20 reader equipped with an internal ${ }^{90} \mathrm{Sr} /{ }^{90} \mathrm{Y}$ beta-source, and with a single-grain attachment (Bøtter-Jensen et al., 2003). The OSL signal was stimulated with a green laser (single grain) or blue LEDs (large aliquot) and detected in the near-UV spectrum (Hoya U-340 filter). The infra-red stimulated luminescence (IRSL) signals were stimulated with at $140-\mathrm{mW}$ with a $830-\mathrm{nm}$ IR laser (90\%) power (single-grain aliquot) or with IR LEDs (large aliquot) or and were detected in the blue wavelength (Schott BG-39 with a 410-nm interference filter and with an additional RG-780 filter for singlegrain measurements).

Modified single-aliquot regenerative (SAR) protocols (Murray and Wintle, 2000) were applied to measure single-grain quartz (OSL; Table S2) and feldspar (post-IRIR 225 ; Buylaert et al., 2012; Table S2) equivalent doses $\left(D_{e}\right)$. The OSL (quartz) signal was integrated over the first $0.1 \mathrm{~s}$ minus a background averaged over the last $2 \mathrm{~s}$, and $\mathrm{IR}_{50}$ and post-IRIR 225 (feldspar) signals over the first $0.5 \mathrm{~s}$ minus a background averaged over the last 2s. Dose-response curves were reconstructed using an exponential fitting, including 2.5\% instrumental uncertainty for single-grain $D_{e}$ calculation. Single-grain $D_{e}$ measurements were kept for further analysis with the following criteria: recycling ratio within $10 \%$, recuperation ratio $<5 \%$, and $D_{e}<$ $2 D_{0}$. The suitability of each SAR protocol was checked by conducting dose-recovery and residual tests for each sample at the single-grain level for feldspar IRSL measurement, and for one representative sample using large aliquots for quartz OSL measurement (due to the very low proportion, i.e. $\leq 2 \%$, of quartz grains, emitting suitable luminescence signal). For all samples, recovered dose after removal of the residual signal was within $10 \%$ of the given dose (within uncertainty), except for the post-IRIR 225 signal of one sample

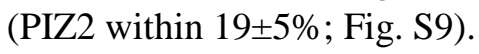

\section{Data analysis: partial bleaching evaluation and burial dose determination}

Quartz OSL single-grain data could be collected for only three out of eight samples (EYP1, OYT1, SPC5), due to the very low luminescence sensitivity of quartz. Feldspar ( $\operatorname{IR}_{50}$ and post-IRIR 225 ) single-grain data were collected for all samples. However, analysis for burial dose determination were conducted using the $\mathrm{IR}_{50}$ signal only, as the post-IRIR 225 natural signal was systematically saturated for a large grain proportion (>30-50\%; Fig. S14).

Burial doses used for age determination were calculated from single grain $D_{e}$ distributions using the Central Age Model (CAM; Galbraith et al., 1999), or the Finite Mixture Model (FMM; Galbraith and Green, 1990) in case of partial bleaching (i.e. incomplete reset of luminescence signal prior deposition) diagnosis. The FMM was run for multiple components (testing 2, 3, and 4 components), assuming a sigma-b $\left(\sigma_{b}\right)$ value of 
0.25 (quartz) or 0.35 (feldspar-IR ${ }_{50}$ ) for well-bleached sediments in glaciofluvial environments (Gaar et al., 2014; 2019; Gribenski et al., 2018; Smedley et al., 2016; 2019). Final selection of the FMM component and associated burial dose (FMM $D_{e}$ ) was based on statistical indicators (BIC and likelihood; Bailey and Arnold, 2006; Jacobs et al., 2008), the significance of the identified “youngest” $D_{e}$ subpopulation ( $p_{0}>$ 0.05 ), and on visual inspection of the single-grain $D_{e}$ distributions. The robustness of the approach was investigated by testing the sensitivity of the FFM $D_{e}$ to varying $\sigma_{b}$ values $\left(0.30-0.40\right.$; tests run on $\operatorname{IR}_{50}$ distribution; Fig. S12) and by checking the consistency between burial doses obtained using the FMM and other sub-statistical models (e.g. Minimum Age Model - 4 parameters; Galbraith et al., 1999).

Samples collected in such proximal glaciofluvial environment (Fig. S1) are typically prone to partial bleaching issue, due to the characteristic sediment transport mode over short distances and in turbid waters, limiting the grain exposure to natural light (Duller, 2006; Fuchs and Owen, 2008). The significant increase in CAM $D_{e}$ values and/or in the saturated-grain proportion between the signals with different bleaching rates (i.e. decreasing resetting probability going from quartz OSL, IR ${ }_{50}$, to post-IRIR ${ }_{225}$; Buylaert et al., 2012; Murray et al., 2012; Colarossi et al., 2015) suggest limited light exposure of grains prior deposition. Final partial bleaching diagnostic was established for all the quartz and feldspar single-grain dataset but one (quartz OSL signal for EYP1 sample), based on the complex (asymmetrical and multimodal) and largely-spread (overdispersion OD $>30 \%$ for quartz and OD $>40 \%$ for feldspar) single-grain $D_{e}$ distributions.

Fading measurements ( $\mathrm{IR}_{50}$ ) were conducted following two different protocols: at the single-grain level and using 4-mm aliquots. Both approaches provided similar outcomes when comparing single-grain (weighted average) and 4-mm aliquots (arithmetic mean) g-values within two standard errors, except for PIZ1 (Fig. S10). No relationship could be identified between single-grain $D_{e}$ and g-value (Fig. S11). Based on the lower inter-aliquot variability and the higher signal magnitude (better counting statistics), sampleindividual g-values from 4-mm aliquot were used for correction of burial doses (following Huntley and Lamothe, 2001).

Sample-individual dose rates for age calculation were calculated using $\mathrm{U}$, Th and $\mathrm{K}$ concentrations measured by high-resolution gamma spectrometry (Table S5) on bulk sediment using the online DRAC calculator (Durcan et al., 2015). A water content of $10 \pm 5 \%$ was assumed to take in account large variations over the considered time. For feldspar $\left(\mathrm{IR}_{50}\right)$ dose rate calculation, an internal K-content of $12.5 \pm 0.5 \%$ (Huntley and Baril, 1997) and an alpha efficiency value of 0.15 \pm 0.05 (Balescu and Lamothe, 1994) were used. 


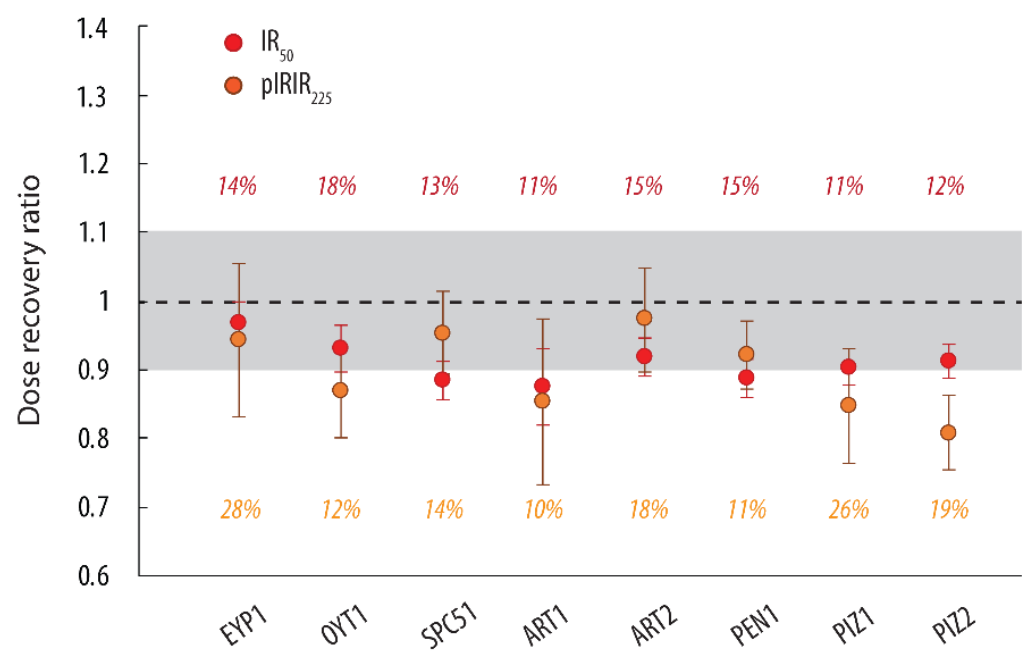

Figure S9: Dose recovery tests for feldspar $I_{50}$ and post-IRIR 225 protocols (CAM recovery dose from single-grain measurements, 1 SG disc for each sample) with intrinsic overdispersion values (given in \%).

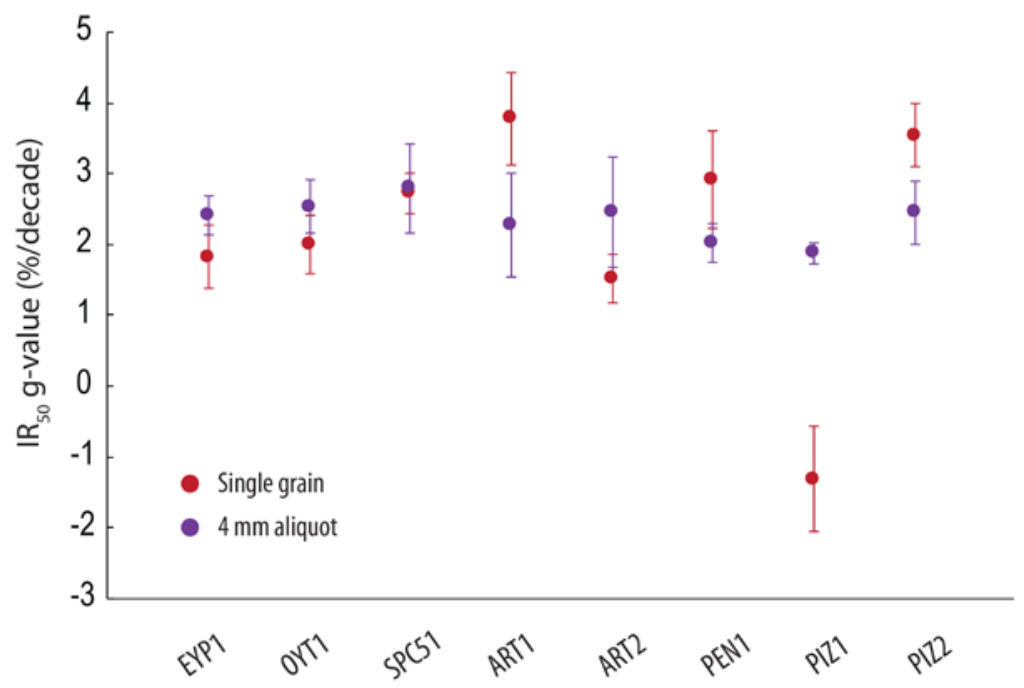

Figure S10: Individual sample g-values (two standard error) for IR 50 feldspar from single-grain measurements (1-2 SG discs for each sample; weighted average, in red) and from 4-mm aliquot measurements (3 discs for each sample; arithmetic mean, in purple). 

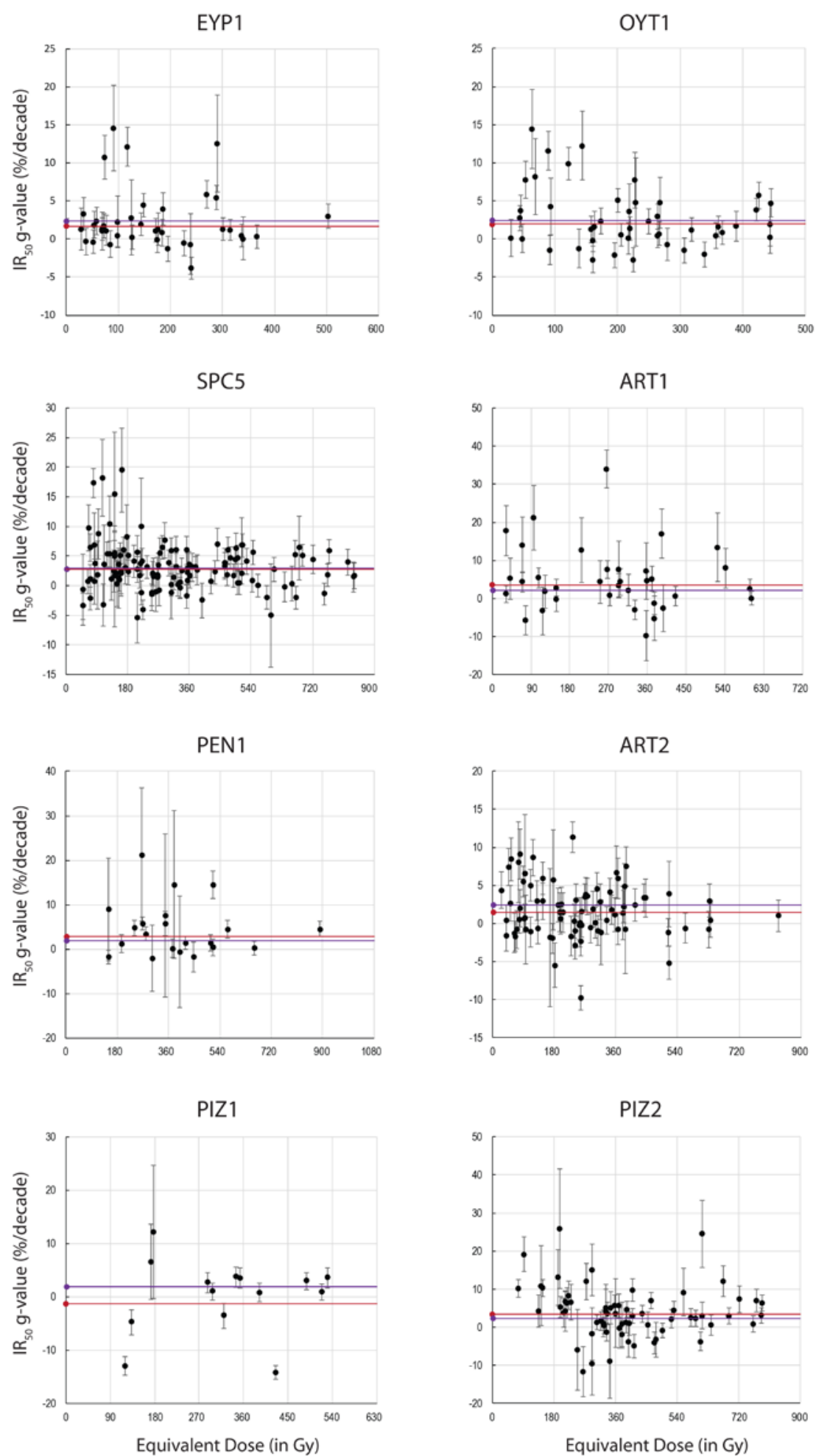

$\bullet-$ Individual single grain g-values $\bullet-$ Weighted average single grain g-value $\bullet-$ Mean 4 mm aliquot g-value

Figure S11: Individual single-grain $\mathrm{IR}_{50}$ g-values plotted against corresponding single-grain $D_{e}$ (black dots). Sample g-values from single-grain (weighted average; red line) and 4-mm aliquot (arithmetic mean; purple line) are also indicated. Some samples count significantly less single-grain g-values due to the non-measurable fading at an acceptable level of sensitivity and /or the absence of corresponding single-grain $D_{e}$. 


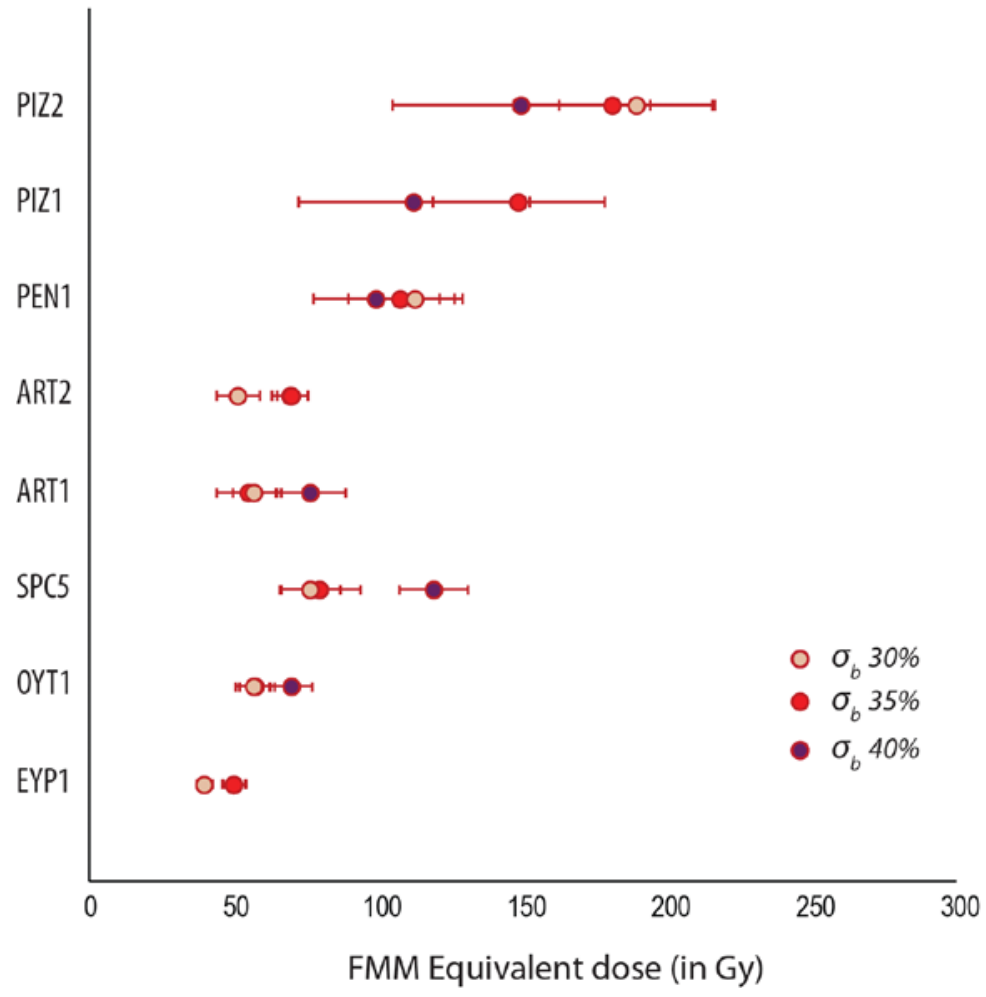

Figure S12: IR 50 feldspar burial dose (one sigma error; non-fading corrected) obtained when applying the FMM model (FMM $D_{e}$ ) using $\sigma_{b}$ values at 30, 35, 40\%. In most cases, FMM $D_{e}$ agree within $1 \sigma$ error using different $\sigma_{b}$ values. For ART2 and EYP1, FMM $D_{e}$ agree within $2 \sigma$ error. Only for SPC5, a significant difference persists between 30-35\% and $40 \% \sigma_{b}$ values. However, IR $_{50}$ feldspar-age using $30-35 \% \sigma_{b}$ value agrees within error with the associated OSL quartz age, hence we selected $\sigma_{b}$ of $35 \%$ for $\mathrm{IR}_{50}$ feldspar age calculation. For PIZ1, the proportion of the minimum subpopulation extracted when applying the FMM model with $30 \% \sigma_{b}$ is not significant $\left(p_{0}<0.05\right)$, hence no FMM $D_{e}$ is provided.

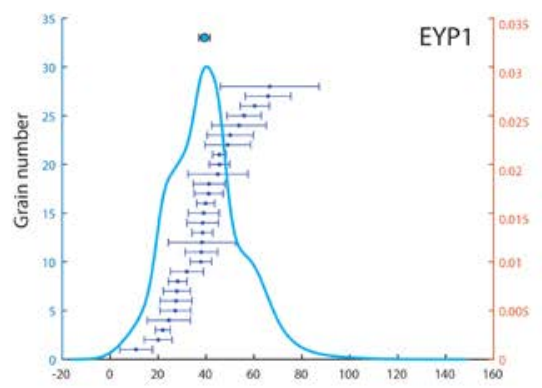

Equivalent dose (in Gy)

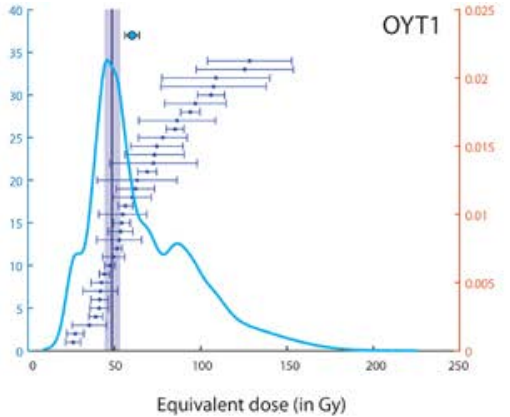

CAM I FMM $\left(\sigma_{b}=25 \%\right)$

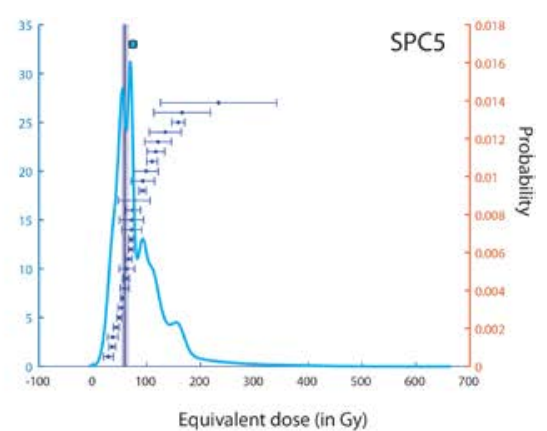
Figure S13: Single-grain OSL quartz $D_{e}$ distribution for EYP1, OYT1 and SPC5 samples (suitable signals/statistics),
and burial doses obtained using the CAM (top circle) and FMM (vertical line/envelope) models. No FMM model was run for EYP1 due the limited overdispersion of this dataset $(\mathrm{OD}<25 \%)$. 

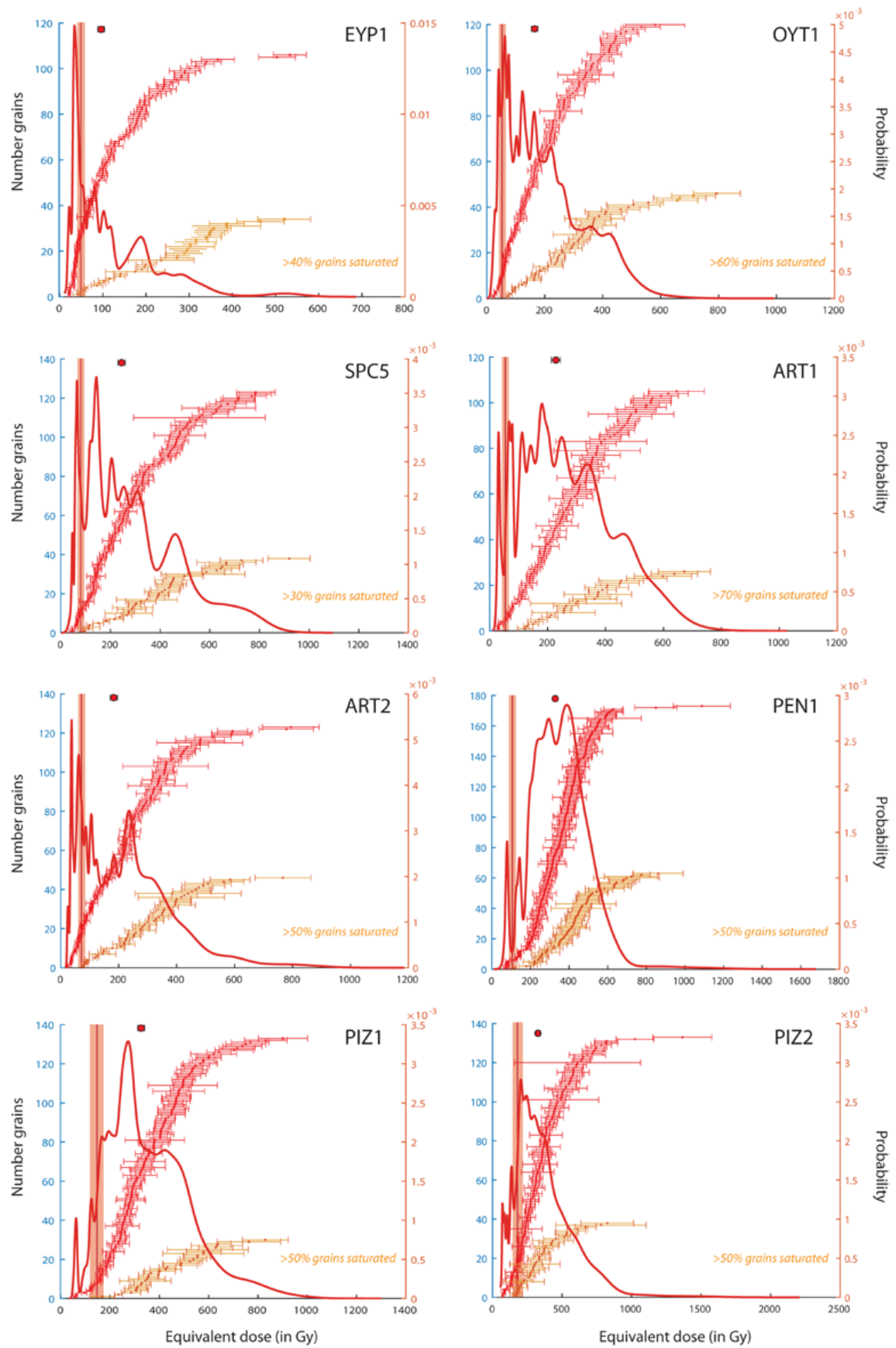

$$
\mathbb{R}_{50} \text { post-IRIR } \mathrm{R}_{225} \mathrm{CAM}_{\text {IRSO }} \| \mathrm{FMM}_{\text {IRSO }}\left(\sigma_{b}=35 \%\right)
$$

Figure S14: $\mathrm{IR}_{50}$ and post-IRIR ${ }_{225}$ single-grain $D_{e}$ distribution (non-fading corrected) for all samples. Probability distribution and burial doses (non-fading corrected) obtained using the CAM (top circle) and the FMM (vertical envelope) models are only provided for the $\mathrm{IR}_{50}$ signal, as a large proportion of grains were saturated when considering the post-IRIR 225 signal. 
Table S2: SAR protocols used for feldspar and quartz single-grain equivalent doses

\begin{tabular}{ll} 
Feldspar post-IRIR & Quartz OSL \\
\hline Dose & Dose \\
Preheat at $250^{\circ} \mathrm{C}$ for $60 \mathrm{~s}$ & Preheat at $220^{\circ} \mathrm{C}$ for $10 \mathrm{~s}$ \\
SG IRSL (laser) at $50^{\circ} \mathrm{C}$ for $5 \mathrm{~s}$ & IRSL (diodes) at $125^{\circ} \mathrm{C}$ for $40 \mathrm{~s}$ \\
SG IRSL (laser) at $225^{\circ} \mathrm{C}$ for $5 \mathrm{~s}$ & SG Green OSL (laser) at $125^{\circ} \mathrm{C}$ for $5 \mathrm{~s}$ \\
Test dose (500s) & Test dose (500s) \\
Preheat at $250^{\circ} \mathrm{C}$ for $60 \mathrm{~s}$ & Preheat at $220^{\circ} \mathrm{C}$ for $10 \mathrm{~s}$ \\
SG IRSL (laser) $50^{\circ} \mathrm{C}$ for $5 \mathrm{~s}$ & IRSL (diodes) at $125^{\circ} \mathrm{C}$ for $40 \mathrm{~s}$ \\
SG IRSL (laser) at $225^{\circ} \mathrm{C}$ for $5 \mathrm{~s}$ & SG Green OSL (laser) at $125^{\circ} \mathrm{C}$ for $5 \mathrm{~s}$ \\
\hline
\end{tabular}

Table S3: Details of single-grain $\mathrm{IR}_{50}$ feldspar measurements and age determination

\begin{tabular}{|c|c|c|c|c|c|c|c|c|c|}
\hline $\begin{array}{l}\text { Sample } \\
\text { ID }\end{array}$ & $\begin{array}{l}\text { n grains } \\
\left(\mathbf{n} / \mathbf{N}, \%^{1}\right)\end{array}$ & $\begin{array}{c}\text { Total } \\
\text { OD } \\
(\%)\end{array}$ & $\begin{array}{l}\text { CAM } D_{e} \\
\text { (Gy) }\end{array}$ & skewness & kurtosis & $\begin{array}{c}\text { FMM } D_{e}{ }^{2} \\
\left(G y ; \sigma_{b}\right. \\
0.35)\end{array}$ & $\begin{array}{c}\text { g-value } \\
\text { (\% per } \\
\text { decade) }\end{array}$ & $\begin{array}{c}\text { Dose rate } \\
\text { (Gy/ka) }\end{array}$ & $\begin{array}{l}\text { Age } \\
\text { (ka) }\end{array}$ \\
\hline EYP1 & $\begin{array}{c}106 \\
(35 \%)\end{array}$ & 78 & $96.0 \pm 7.3$ & 1.44 & 5.33 & $\begin{array}{l}49.9 \pm 3.7 \\
(F M M 2)\end{array}$ & $2.4 \pm 0.1$ & $2.14 \pm 0.12$ & $29.4 \pm 2.8$ \\
\hline OYT1 & $\begin{array}{c}120 \\
(40 \%)\end{array}$ & 73 & $164.8 \pm 11.1$ & 0.65 & 2.52 & $\begin{array}{l}57.5 \pm 6.8 \\
(F M M 3) \\
\end{array}$ & $2.5 \pm 0.2$ & $2.27 \pm 0.12$ & $32.4 \pm 4.3$ \\
\hline SPC5 & $\begin{array}{c}123 \\
(41 \%)\end{array}$ & 68 & $244.8 \pm 15.1$ & 0.75 & 2.72 & $\begin{array}{l}79.7 \pm 14.0 \\
\text { (FMM 3) }\end{array}$ & $2.8 \pm 0.3$ & $2.53 \pm 0.13$ & $41.6 \pm 7.9$ \\
\hline ART1 & $\begin{array}{c}105 \\
(12 \%)\end{array}$ & 68 & $228.6 \pm 15.4$ & 0.37 & 2.29 & $\begin{array}{c}55.2 \pm 11.1 \\
(F M M 3)\end{array}$ & $2.3 \pm 0.4$ & $2.03 \pm 0.12$ & $33.8 \pm 7.3$ \\
\hline ART2 & $\begin{array}{c}123 \\
(41 \%) \\
\end{array}$ & 75 & $182.8 \pm 12.6$ & 1 & 4.37 & $\begin{array}{l}70.2 \pm 5.3 \\
\text { (FMM 3) }\end{array}$ & $2.5 \pm 0.4$ & $2.20 \pm 0.12$ & $40.6 \pm 4.2$ \\
\hline PEN1 & $\begin{array}{c}173 \\
(29 \%)\end{array}$ & 43 & $328.2 \pm 11.0$ & 0.9 & 6.42 & $\begin{array}{c}107.9 \pm 18.1 \\
(F M M ~ 2)\end{array}$ & $2.0 \pm 0.1$ & $2.09 \pm 0.12$ & $\begin{array}{c}63.0 \pm 11 \\
4\end{array}$ \\
\hline PIZ1 & $\begin{array}{c}133 \\
(22 \%)\end{array}$ & 48 & $325.9 \pm 13.9$ & 0.75 & 3.49 & $\begin{array}{c}148.6 \pm 29.5 \\
(F M M 2)\end{array}$ & $1.9 \pm 0.1$ & $2.94 \pm 0.14$ & $\begin{array}{c}60.8 \pm 12 \\
3\end{array}$ \\
\hline PIZ2 & $\begin{array}{c}133 \\
(22 \%) \\
\end{array}$ & 52 & $326.4 \pm 15.3$ & 1.45 & 6.83 & $\begin{array}{c}181.2 \pm 34.4 \\
(F M M \text { 2) }\end{array}$ & $2.5 \pm 0.2$ & $3.05 \pm 0.13$ & $\begin{array}{c}76.4 \pm 15 \\
1\end{array}$ \\
\hline
\end{tabular}

${ }^{1}$ Percentage of grains used for analysis (n) compared to the total number of measured grains (N). ${ }^{2} \mathrm{FMM} D_{e}$ used for age calculation. For each sample, the number of components of the selected FMM model is indicated; ${ }^{3}$ mean and standard error g-value from fading measurements using 4-mm aliquots.

Table S4: Details of single-grain OSL quartz measurements and age determination

\begin{tabular}{|c|c|c|c|c|c|c|c|c|c|}
\hline $\begin{array}{c}\text { Sample } \\
\text { ID }\end{array}$ & $\begin{array}{c}\text { n grains } \\
\mathbf{( n / N , \% )}\end{array}$ & $\begin{array}{c}\text { Total } \\
\text { OD } \\
\mathbf{( \% )}\end{array}$ & $\begin{array}{c}\text { CAM } \\
\boldsymbol{D}_{\boldsymbol{e}} \mathbf{( G y )}\end{array}$ & skewness & kurtosis & $\begin{array}{c}\text { FMM } \boldsymbol{D}_{\boldsymbol{e}} \\
\mathbf{( G y ;} \mathbf{\sigma b}_{\mathbf{b}} \\
\mathbf{0 . 2 5} \mathbf{1}^{\mathbf{1}}\end{array}$ & $\begin{array}{c}\text { Age } \\
\text { model }\end{array}$ & $\begin{array}{c}\text { Dose rate } \\
\mathbf{( G y / k a )}\end{array}$ & Age (ka) \\
\hline EYP1 & $28(2 \%)$ & 24 & $39.4 \pm 2.3$ & 0.11 & 2.48 & - & CAM & $1.20 \pm 0.05$ & $32.9 \pm 2.3$ \\
\hline OYT1 & $34(2 \%)$ & 36 & $60.2 \pm 4.1$ & 0.67 & 2.45 & $48.7 \pm 4.6$ & FMM 2 & $1.34 \pm 0.06$ & $36.4 \pm 3.8$ \\
\hline SPC5 & $27(2 \%)$ & 39 & $74.6 \pm 6.3$ & 1.38 & 4.77 & $60.2 \pm 6.4$ & FMM 2 & $1.56 \pm 0.07$ & $38.6 \pm 4.5$ \\
\hline
\end{tabular}

${ }^{1}$ using a $\sigma_{b}$ of 0.3 results in FMM $D_{e}$ with less than $5 \%$ difference. 
Table S5: Element concentrations from high-resolution gamma spectrometry used for dose-rate calculation (see Tables S3 and S4 for output dose rates)

\begin{tabular}{|c|c|c|c|}
\hline $\begin{array}{c}\text { Sample } \\
\text { ID }\end{array}$ & $\mathbf{U}$ (ppm) & Th (ppm) & ${ }^{\mathbf{4}} \mathbf{K}$ (\%) \\
\hline EYP1 & $0.89 \pm 0.11$ & $3.97 \pm 0.08$ & $0.79 \pm 0.01$ \\
\hline OYT1 & $0.53 \pm 0.17$ & $3.02 \pm 0.02$ & $1.07 \pm 0.01$ \\
\hline SPC5 & $1.26 \pm 0.31$ & $5.91 \pm 0.13$ & $0.98 \pm 0.01$ \\
\hline ART1 & $0.79 \pm 0.1$ & $3.73 \pm 0.11$ & $0.90 \pm 0.01$ \\
\hline ART2 & $0.85 \pm 0.23$ & $2.63 \pm 0.08$ & $0.78 \pm 0.01$ \\
\hline PEN1 & $0.6 \pm 0.11$ & $2.34 \pm 0.08$ & $1.01 \pm 0.01$ \\
\hline PIZ1 & $1.27 \pm 0.16$ & $7.1 \pm 0.24$ & $1.43 \pm 0.02$ \\
\hline PIZ2 & $1.20 \pm 0.13$ & $6.16 \pm 0.2$ & $1.57 \pm 0.02$ \\
\hline
\end{tabular}

\section{References}

Balescu, S., and Lamothe, M., 1994, Comparison of TL and IRSL age estimates of feldspar coarse grains from waterlain sediments: Quaternary Science Reviews, v. 13, p. 437-444, https://doi.org/10.1016/0277-3791(94)900566.

Bailey, R.M., and Arnold, L.J., 2006, Statistical modelling of single grain quartz De distributions and an assessment of procedures for estimating burial dose: Quaternary Science Reviewsm v. 25, p. 2475-2502, https://doi:10.1016/j.quascirev.2005.09.012.

Bøtter-Jensen L, Andersen CE, Duller GAT et al., 2003, Developments in radiation, stimulation and observation facilities in luminescence measurements: Radiation Measurements, v. 37, p. 535-541, https://doi.org/10.1016/S13504487(03)00020-9.

Buylaert, J-P., Jain, M., Murray, A.S., Thomsen, K.J., Thiel, C., and Sohbati, R., 2012, A robust feldspar luminescence dating method for Middle and Late Pleistocene sediments: Borea, v. 41, 435-451, http://doi.org/10.1111/j.15023885.2012.00248.x.

Colarossi, D., Duller, G.A.T., Roberts, H.M., Tooth, S., and Lyons, R., 2015, Comparison of paired quartz OSL and feldspar post-IR IRSL dose distributions in poorly bleached fluvial sediments from South Africa: Quaternary Geochronology, v. 30, p. 233-238, http://doi.org/10.1016/j.quageo.2015.02.015.

Duller, G.A.T., 2006, Single grain optical dating of glacigenic deposits: Quaternary Geochronology, v. 1, p. 296-304, https://doi.org/10.1016/j.quageo.2006.05.018.

Durcan, J.A., King, G.E., and Duller, G.A.T., 2015, DRAC: Dose Rate and Age Calculator for trapped charge dating: Quaternary Geochronology, v. 28, p 54-61, http://dx.doi.org/10.1016/j.quageo.2015.03.012.

Fuchs, M. and Owen, L.A., 2008, Luminescence dating of glacial and associated sediments: review, recommendations and future directions: Boreas, v. 37, p. 636-659, https://doi.org/10.1111/j.1502-3885.2008.00052.x.

Gaar, D., Lowick, S.E. and Preusser, F., 2014, Performance of different luminescence approaches for the dating of known-age glaciofluvial deposits from northern Switzerland: Geochronometria, v. 41, p. 65-80, doi: 10.2478/s13386013-0139-0.

Gaar, D., Graf, H.R. and Preusser, F., 2019, New chronological constraints on the timing of Late Pleistocene glacier advances in northern Switzerland: E\&G Quaternary Science Journal, v. 68, 53-73, https://doi.org/10.5194/egqsj-6853-2019. 
Galbraith, R.F., and Green, P.F., 1990, Estimating the component ages in a finite mixture: Nuclear Tracks and Radiation Measurements, v. 17, p. 197-206, https://doi.org/10.1016/1359-0189(90)90035-V.

Galbraith, R.F., Roberts, R.G., Laslett, G.M., Yoshida, H. and Olley, J.M., 1999, Optical dating of single and multiple grains of quartz from Jinmium rock shelter, northern Australia: Part I, experimental design and statistical models: Archaeometry, v. 41, p. 339-364, https://doi.org/10.1111/j.1475-4754.1999.tb00987.x.

Gribenski, N., Jansson, K.N., Preusser, F., Harbor, J.M., Stroeven, A., Trauerstein, M., Blomdin, R., Heyman, J., Caffee, M.W., Lifton, N., and Zhang, W., 2018, Re-evaluation of MIS 3 glaciation using cosmogenic radionuclide and single grain luminescence ages, Kanas Valley, Chinese Altai: Journal of Quaternary Science, v. 33, p. 55-67, https://doi.org/10.1002/jqs.2998.

Huntley, D.J. and Baril, M.R., 1997, The K content of the K-feldspars being measured in optical dating or in thermoluminescence dating: Ancient TL, v. 15, p. 11-13.

Huntley, D.J. and Lamothe, M., 2001, Ubiquity of anomalous fading in K-feldspars and the measurement and correction for it in optical dating: Canadian Journal of Earth Sciences, v. 38, p. 1093-1106, https://doi.org/10.1139/cjes-38-7-1093.

Jacobs, Z., Wintle, A.G., Duller, G.A.T., Roberts, R.G., and Wadley, L., 2008, New ages for the post-Howiesons Poort, late and final Middle Stone Age at Sibudu, South Africa: Journal of Archaeological Science, v. 35, p. 17901807, https://doi.org/10.1016/j.jas.2007.11.028.

Lowick, S. E., Büchi, M., Gaar, D., Graf, H. R., and Preusser, F., 2015, Luminescence dating of Middle Pleistocene proglacial deposits from northern Switzerland: methodological aspects and stratigraphical conclusions: Boreas, v. 44, p. 459-482, https://doi.org/10.1111/bor.12114.

Mandier, P., 1988, Le relief de la moyenne vallée du Rhône au Tertiaire et au Quaternaire : essai de synthèse paléogéographique. Bureau de Recherches Géologiques et Minières, Orléans, 865 pp.

Murray, A.S., and Wintle, A.G., 2000. Luminescence dating of quartz using an improved single- aliquot regenerativedose protocol: Radiation Measurements, v. 32, p. 57-73, https://doi.org/10.1016/S1350-4487(99)00253-X

Murray, A.S., Thomsen, K.J., Masuda, N., Buylaert, J-P., and Jain, M., 2012, Identifying well-bleached quartz using the different bleaching rates of quartz and feldspar luminescence signals: Radiation Measurements, v. 47, p. 688-695, https://doi.org/ 10.1016/j.radmeas.2012.05.006.

Roattino, T., Crouzet, C., Buoncristiani, J-F., Tissoux, H., 2021, Geometry of glaciofluvial deposits and dynamics of the Lyonnais lobe ice front during the last glacial period (France, Northern Alps): Earth Science Bulletin BSGF, Accepted

Smedley, R.K., Glasser, N.F. and Duller, G.A.T., 2016, Luminescence dating of glacial advances at Lago Buenos Aires ( $\sim 6^{\circ}$ S), Patagonia: Quaternary Science Reviews, v. 134, p. 59-73, doi: 10.1016/j.quascirev.2015.12.010.

Smedley, R.K., Buylaert, J-P., and Újvári, G., 2019, Comparing the accuracy and precision of luminescence ages for partially bleached sediments using single grains of K-feldspar and quartz: Quaternary Geochronology, v. 53, p. 101007, https://doi.org/10.1016/j.quageo.2019.101007. 